\title{
Treadmill exercise alleviates impairment of spatial learning ability through enhancing cell proliferation in the streptozotocin-induced Alzheimer's disease rats
}

\author{
Young-Je Sim \\ Department of Physical Education, Kunsan National University, Gunsan, Korea
}

\begin{abstract}
Alzheimer's disease is the most common cause of dementia. This disease is a progressive and irreversible brain disorder accompanied with severe learning and memory impairment. Exercise increases cognitive ability, attenuates motor deficits, increases new neuron formation, and ameliorates neurological impairments in several neurodegenerative diseases. This study investigated the effects of treadmill exercise on spatial learning ability in relation with cell proliferation in the hippocampus. The rat model of Alzheimer's disease was induced by intracerebroventricular (ICV) injection of streptozotocin (STZ) using a stereotaxic instrument. The rats in the exercise groups were forced to run on a treadmill for once 30 min daily for 28 consecutive days starting at 3 days after the ICV injection of STZ. Radial 8-arm maze test was conducted for the spatial learning ability. New neuron formation in the hippocampus was detected by 5-bromo-2'-deoxyuridine (BrdU) immunohistochemistry. Brain-de-
\end{abstract}

rived neurotrophic factor (BDNF) and tyrosine kinase $B$ (TrkB) expressions were examined by western blot analysis. The present results show that ICV injection of STZ impaired spatial learning ability. Decreased cell proliferation with decrement of BDNF and TrkB expressions in the hippocampus were observed in the STZ-induced Alzheimer's disease rats. However, treadmill exercise alleviated deficits of spatial learning ability. Treadmill exercise enhanced cell proliferation and increased BDNF and TrkB expressions in the rats with ICV injection of STZ. The present study suggests that treadmill exercise can be a useful strategy for treating memory impairment induced by several neurodegenerative diseases.

Keywords: Alzheimer's disease, Treadmill exercise, Spatial learning ability, Cell proliferation, Brain-derived neurotrophic factor

\section{INTRODUCTION}

Alzheimer's disease $(\mathrm{AD})$ is characterized by a complex of neuropathological, biochemical, and behavioral symptoms. AD gradually impairs learning ability and memory function, and the incidence of $A D$ is $50-80 \%$ of dementia cases (Hosseini et al., 2013). Those with Alzheimer's live on average $8 \mathrm{yr}$ after their symptoms become noticeable to others, but survival rate ranges from 4 to 20 yr, depending on age and other health conditions (Hosseini et al., 2013).

The pathogenesis of $\mathrm{AD}$ and the cause are not known. However, in pathologic hypothesis for $\mathrm{AD}$, there has been growing interest on the insulin signaling, and insulin resistance is involved in

the pathogenesis of cognitive deficits in the neurodegenerative diseases (Hoyer, 2004; de la Nonte and Wands, 2005; Salkovic-Petrisic and Hoyer, 2007). The insulin-resistant brain state is thought to play a pivotal role in the pathogenesis of neurodegenerative disorders including AD (Lopez-Lopez et al., 2007). In particular, alteration of energy metabolism by enhancing of insulin resistance changes the memory function with decrement of neuronal growth factors in the brain (Dietrich et al., 2008; Freiherr et al., 2013).

Hippocampus is the important brain area in learning ability and memory function (Eichenbaum, 2004). In addition, hippocampus is one of the brain areas that cell proliferation continues throughout life in the adult mammals including humans (Eriks-

${ }^{*}$ Corresponding author: Young-Je Sim

Department of Physical Education, Kunsan National University, 558 Daehak-ro, Gunsan 573-701, Korea

Tel: +82-63-469-4647, Fax: +82-63-469-7430, E-mail: simyoungje@gmail.com

Received: April 17, 2014 / Accepted: April 21, 2014 
son et al., 1998; Lee et al., 2013). Alterations of hippocampal structures are implicated in the early symptoms of the $\mathrm{AD}$ (Braak et al., 2006), and neurons in the hippocampus are known to be vulnerable to the $\mathrm{AD}$ (Alkam et al., 2007).

Brain-derived neurotrophic factor (BDNF) is a small dimeric protein, and BDNF acts through high affinity binding with its receptor, tyrosin kinase B (TrkB). BDNF modulates neuronal growth and survival, and BDNF is implicated in learning and memory processes; therefore, dysfunction in BDNF is accompanied by cognitive deficits. Especially, BDNF is involved in the AD-related decline of neurogenesis, and the level of nerve growth factor is also decreased with AD (Chadwick et al., 2011; Hubka, 2006). This was also supported by the observation that administration of neurotrophic factors successfully improved the AD-related decrease in hippocampal neurogenesis (Hubka, 2006),

The beneficial effects of physical exercise on brain function and brain plasticity have been observed in numerous studies. Physical exercise has been recommended as a both preventive and therapeutic regimen in the management of patients with $\mathrm{AD}$ (Archer et al., 2011; Kim et al., 2014). However, the mechanisms of physical exercise on spatial learning ability under the $\mathrm{AD}$ conditions are not fully clarified.

We investigated the effects of treadmill exercise on spatial learning memory ability in relation with cell proliferation in the hippocampus using streptozotocin (STZ)-induced AD rats. For this study, radial 8-arm maze test, immunohistochemistry for 5-bromo-2'-deoxyuridine (BrdU), and western blot for BDNF and TrkB were performed.

\section{METHERIALS AND METHODS}

\section{Animals and treatments}

Adult male Sprague-Dawley rats, weighing $430 \pm 20 \mathrm{~g}$ (40 weeks old), were used for the experiments. The experimental procedures were performed in accordance with the animal care guidelines of the National Institutes of Health $(\mathrm{NIH})$ and the Korean Academy of Medical Sciences. The rats were housed under controlled temperature $\left(23 \pm 2^{\circ} \mathrm{C}\right)$ and lighting $(08: 00$ to $20: 00 \mathrm{~h})$ conditions with food and water available ad libitum. The animals were randomly divided into the following four groups $(\mathrm{n}=10$ in each group): sham-operation group, sham-operation and treadmill exercise group, AD-induced group, and AD-induced and treadmill exercise group.

All rats received $50 \mathrm{mg} / \mathrm{kg}$ BrdU (Sigma Chemical Co., St. Louis, MO, USA) intraperitoneally $30 \mathrm{~min}$ before the starting of treadmill exercise, once for 3 days during first week.

\section{Induction of AD}

Animal model of $\mathrm{AD}$ was made using the previously described method (Jee et al., 2008). The rats were anesthetized with Zoletil $50^{\circledR}(10 \mathrm{mg} / \mathrm{kg}$, i.p.; Vibac Laboratories, Carros, France) and placed in the stereotaxic frame. Burr holes were drilled in the skull on both sides over the lateral ventricles using the following coordinates: $0.8 \mathrm{~mm}$ posterior to bregma, $1.5 \mathrm{~mm}$ lateral to sagital suture, and $3.6 \mathrm{~mm}$ beneath the surface of brain. Through a hole drilled in the skull, a 26-gauge needle was lowered manually into each lateral ventricle. The lesioned groups received bilateral intracerebroventricular (ICV) injection of STZ $(1.5 \mathrm{mg} / \mathrm{kg}, 5 \mu \mathrm{L}$ in saline). The rats in the sham-operation group underwent the same surgical procedures, but same volume of saline was injected instead of STZ. After surgery, the rats were housed individually and had access to food and water freely.

\section{Exercise protocol}

The rats in the exercise groups were forced to run on a motorized treadmill. The exercise load consisted of running at speeds of 2 meters $/ \mathrm{min}$ for the first $5 \mathrm{~min}, 5$ meters $/ \mathrm{min}$ for the next $5 \mathrm{~min}$, and then 8 meters $/ \mathrm{min}$ for the last $20 \mathrm{~min}$, at an inclination of $0^{\circ}$. The rats in the exercise groups were scheduled to start treadmill running from 3 days after the ICV injection of STZ, and continued 28 days.

\section{Radial 8-arm maze test}

Spatial learning ability was determined using a radial 8-arm maze apparatus, according to the previously described method (Seo et al., 2013). The radial-arm maze apparatus consisted of a central octagonal plate $(30 \mathrm{~cm}$ in diameter) and 8 radiating arms $(50 \mathrm{~cm}$ in length and $10 \mathrm{~cm}$ in width). The apparatus was placed $1 \mathrm{~m}$ above the floor. A small receptacle filled with water $3 \mathrm{~cm}$ in diameter and $1 \mathrm{~cm}$ in depth) was located at the end of the arms. The rats were trained three times before the radial 8-arm maze test. The rats were deprived of water for $24 \mathrm{~h}$, and were allowed to explore the water during test. The test was conducted on the 28 days after starting the treadmill exercise. The time spent in seeking water at the end of each arm was counted. The test was terminated when a rat found water in all 8 arms or when $>8 \mathrm{~min}$ elapsed. Re-entry into the previously visited arms was counted as an error. In addition, the number of correct choice before the first error was counted. 


\section{Tissue preparation}

The animals were sacrificed immediately after determining the spatial learning ability in the radial 8-arm maze test. The rats were anesthetized using Zoletil $50^{\circledR}(10 \mathrm{mg} / \mathrm{kg}$, i.p.; Vibac Laboratories), transcardially perfused with $50 \mathrm{mM}$ phosphate-buffered saline (PBS), and fixed with a freshly prepared solution consisting of $4 \%$ paraformaldehyde in $100 \mathrm{mM}$ phosphate buffer ( $\mathrm{PB}, \mathrm{pH}$ 7.4). Brains were dissected, and storage overnight same fixative, then it was transferred to $30 \%$ sucrose for cryoprotection. For the immunohistochemistry, the slices were coronal sectioned at $40 \mu \mathrm{m}$ thick using a cryostat (Leica, Nussloch, Germany).

\section{Immunohistochemistry for BrdU}

To detect newly generated cells in the dentate gyrus, BrdU-specific immunohistochemistry was performed, according to the previously described method (Kim et al., 2010; Lee et al., 2013). Ten slice sections on average in the dentate gyrus were collected from each rat. The sections of $2.5 \mathrm{~mm}$ to $2.7 \mathrm{~mm}$ posterior from the bregma were used for immunohistochemistry. The sections were first permeabilized by incubation in $0.5 \%$ Triton X-100 in PBS for $20 \mathrm{~min}$, then pretreated in $50 \%$ formamide- $2 \mathrm{x}$ standard saline citrate (SSC) at $65^{\circ} \mathrm{C}$ for $2 \mathrm{~h}$, denaturated in $2 \mathrm{~N} \mathrm{HCl}$ at $37^{\circ} \mathrm{C}$ for $30 \mathrm{~min}$, and rinsed twice in $100 \mathrm{mM}$ sodium borate $(\mathrm{pH}$ 8.5). Afterwards, the sections were incubated overnight at $4^{\circ} \mathrm{C}$ with BrdU-specific mouse monoclonal antibody (1:600; Roche, Mannheim, Germany). The sections were then washed three times with PBS and incubated for $1 \mathrm{~h}$ with a biotinylated mouse secondary antibody (1:200; Vector Laboratories, Burlingame, CA, USA). Then, the sections were incubated for another $1 \mathrm{~h}$ with avidin-peroxidase complex (1:100; Vector Laboratories). For visualization, the sections were incubated in $50 \mathrm{mM}$ Tris- $\mathrm{HCl}$ ( $\mathrm{pH}$ 7.6) containing $0.03 \%$ diaminobenzidine (DAB), $40 \mathrm{mg} / \mathrm{ml}$ nickel chloride, and $0.03 \%$ hydrogen peroxide for $5 \mathrm{~min}$. After BrdU-specific staining, determination of the differentiation of BrdU-positive cells was performed on same section using a mouse anti-neuronal nucleic (NeuN) antibody (1:1,000; Chemicon International, Temecula, CA, USA). The sections were washed three times with PBS, incubated for $1 \mathrm{~h}$ with a biotinylated anti-mouse secondary antibody, and processed with VECTASTAIN ${ }^{\circledR}$ ABC Kit. For staining, the sections were incubated in a reaction mixture consisting of $0.03 \% \mathrm{DAB}$ and $0.03 \%$ hydrogen peroxide for $5 \mathrm{~min}$. The sections were finally mounted onto gelatin-coated slides. The slides were air dried overnight at room temperature, and coverslips were mounted using Permount ${ }^{\circledR}$ (Fisher Scientific).

\section{Western blot for BDNF and TrkB}

Expressions of BDNF and $\operatorname{TrkB}$ were assessed by western blot analysis, according to the previously described method (Kim et al., 2010; Park et al., 2014). The hippocampal tissues were dissected and collected, and then were immediately frozen at $-70^{\circ} \mathrm{C}$. The right hemisphere were homogenized on ice, and lysed in a lysis buffer containing $50 \mathrm{mM}$ HEPES (pH 7.5), $150 \mathrm{mM} \mathrm{NaCl}$, 10\% glycerol, 1\% Triton X-100, 1 mM PMSF, 1 mM EGTA, 1.5 $\mathrm{mM} \mathrm{MgCl} \cdot 6 \mathrm{H}_{2} \mathrm{O}, 1 \mathrm{mM}$ sodium orthovanadate, and $100 \mathrm{mM}$ sodium fluoride. Protein content was measured using a Bio-Rad colorimetric protein assay kit (Hercules, CA, USA). Protein samples $(30 \mu \mathrm{g})$ were separated on sodium dodecyl sulfate-polyacrylamide gel and transferred onto a nitrocellulose membrane. The membranes were incubated with $5 \%$ skim milk in Tris-buffered saline containing $0.1 \%$ Tween-20 and then incubated overnight at $4^{\circ} \mathrm{C}$ with the following primary antibodies: mouse $\beta$-actin antibody (1:1,000; Santa Cruz Biotechnology, Santa Cruz, CA, USA), rabbit BDNF antibody (1:500; Santa Cruz Biotechnology), rabbit TrkB antibody (1:1,000; Santa Cruz Biotechnology) were used as the primary antibodies. Subsequently, membranes were incubated for $1 \mathrm{~h}$ with attempt secondary antibodies (1:2,000; Vector Laboratories), and ban detection was performed using the enhanced chemiluminescence (ECL) detection kit (Santa Cruz Biotechnology).

\section{Data analysis}

The number of BrdU-positive cells in the hippocampal dentate gyrus was counted hemilaterally under a light microscope (Olympus, Tokyo, Japan). The area of the granular layer of the dentate gyrus from each slice was measured by by Image-Pro ${ }^{\circledR}$ Plus image analysis system (Media Cyberbetics Inc., Silver Spring, MD, USA). The number of BrdU-positive cells was expressed as the number of cells per $\mathrm{mm}^{2}$ of granular area in the dentate gyrus. For the confirmation of the expressions of BDNF and TrkB, the detected bands were calculated densitometrically using Molecular Analyst ${ }^{\mathrm{TM}}$, version 1.4.1 (Bio-Rad). Statistical analysis was performed using oneway ANOVA followed by Duncan's post-hoc test, and the results are expressed as the mean \pm standard error of the mean (SEM). Significance was set as $P<0.05$.

\section{RESULTS}

Effect of treadmill exercise on the spatial learning ability in radial 8-arm maze test

The time of successful performance, the number of the correct, and the number of error choice in the radial 8-arm maze test are 

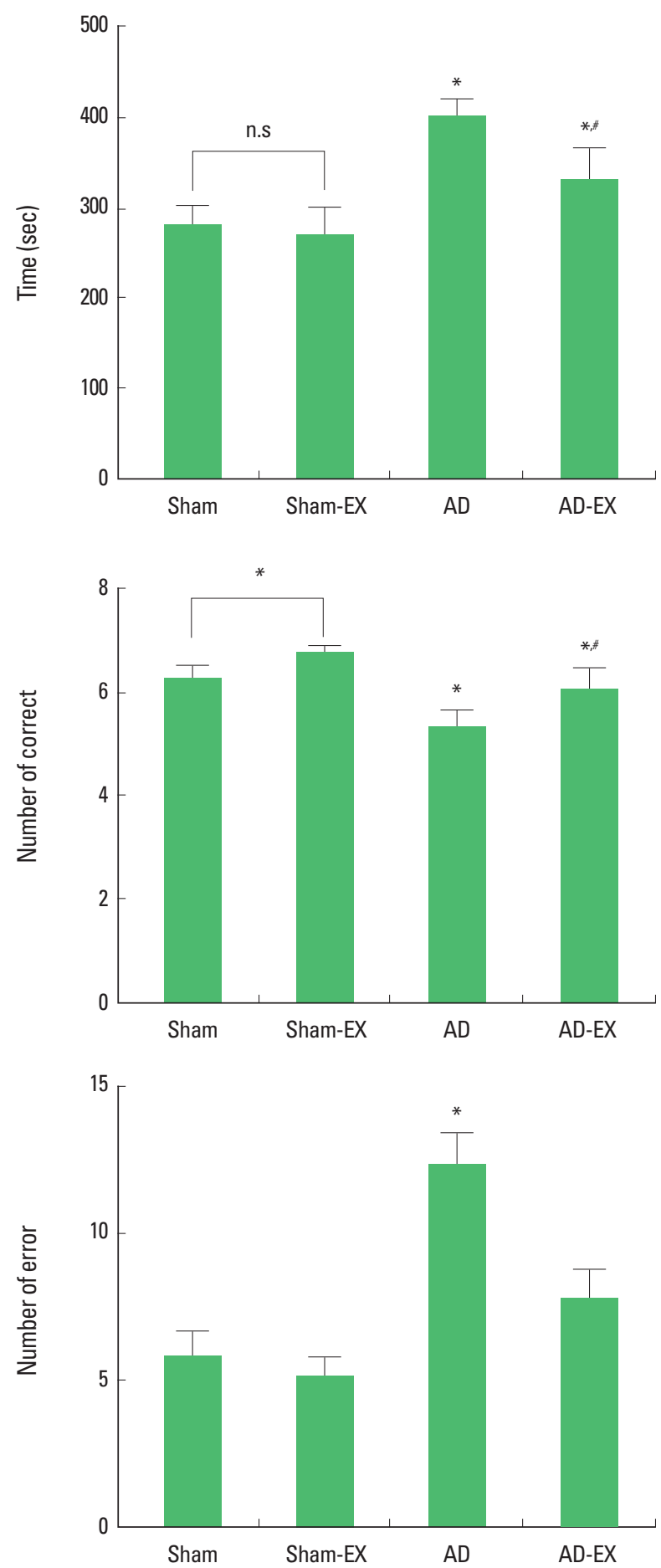

Fig. 1. Effect of treadmill exercise on spatial learning memory in the radial 8-arm maze test. Upper: Time to complete performance. Middle: Number of correct choice. Lower: Number of error choice. Sham: Sham-operation group, Sham-EX: sham-operation and treadmill exercise group, AD: AD-induced group, AD-EX: AD-induced and treadmill exercise group. * Represents $P<0.05$ compared to the sham-operation group. ${ }^{*}$ Represents $P<0.05$ compared to the AD-induced group. n.s: non significantly. presented in Fig. 1. The time of the successful performance was $281.25 \pm 18.20 \mathrm{sec}$ in the sham-operation group, $268.50 \pm 30.03$ sec in the sham-operation and treadmill exercise group, $399.70 \pm 17.98$ sec in the AD-induced group, and 330.10 $\pm 34.97 \mathrm{sec}$ in the AD-induced and treadmill exercise group. The number of correct choice before the first error was $6.25 \pm 0.25$ in the sham-operation group, $6.75 \pm 0.11$ in the sham-operation and treadmill exercise group, $5.30 \pm 0.32$ in the AD-induced group, and $6.00 \pm 0.44$ in the AD-induced and treadmill exercise group. The number of error made before eight successful performance was $5.75 \pm 0.90$ in the sham-operation group, $5.12 \pm 0.65$ in the sham-operation and treadmill exercise group, $12.20 \pm 1.08$ in the AD-induced group, and $7.70 \pm 0.95$ in the AD-induced and treadmill exercise group.

These results show that AD-induced rats showed lower number of correct choice, increased completed time, and higher number of error than those in the sham-operation group. In contrast, treadmill exercise reduced the number of error and completed time, and increased the correct choice in the AD-induced rats.

\section{Effect of treadmill exercise on cell proliferation in the hippocampal dentate gyrus}

Photomicrographs of BrdU-positive cells in the hippocampal dentate gyrus are presented in Fig. 2. The number of BrdU-positive cells was $77.61 \pm 8.58 / \mathrm{mm}^{2}$ in the sham-operation group, $90.79 \pm 10.62 / \mathrm{mm}^{2}$ in the sham-operation and treadmill exercise group, $30.22 \pm 6.15 / \mathrm{mm}^{2}$ in the AD-induced group, and $56.55 \pm 6.23 / \mathrm{mm}^{2}$ in the AD-induced and treadmill exercise group.

These results show that induction of $\mathrm{AD}$ reduced cell proliferation in the hippocampal dentate gyrus whereas treadmill exercise enhanced cell proliferation in the hippocampal dentate gyrus of the AD-induced rats.

\section{Effect of treadmill exercise on the expressions of BDNF and TrkB and in the hippocampus}

When the level of BDNF $(15 \mathrm{kDa})$ in the sham-operation group was set at 1.00, the level of BDNF was $1.33 \pm 0.04$ in the sham-operation and treadmill exercise group, $0.09 \pm 0.07$ in the AD-induced group, and $0.93 \pm 0.02$ in the AD-induced and treadmill exercise group. When the level of TrkB $(95-145 \mathrm{kDa})$ in the sham-operation group was set at 1.00, the level of TrkB was $1.09 \pm 0.08$ in the sham-operation and treadmill exercise group, $0.46 \pm 0.04$ in the $\mathrm{AD}$-induced group, and $0.69 \pm 0.04$ in the $\mathrm{AD}$-induced and treadmill exercise group (Fig. 3).

These results show that induction of AD reduced BDNF and TrkB expressions in the hippocampus, whereas, treadmill exercise 

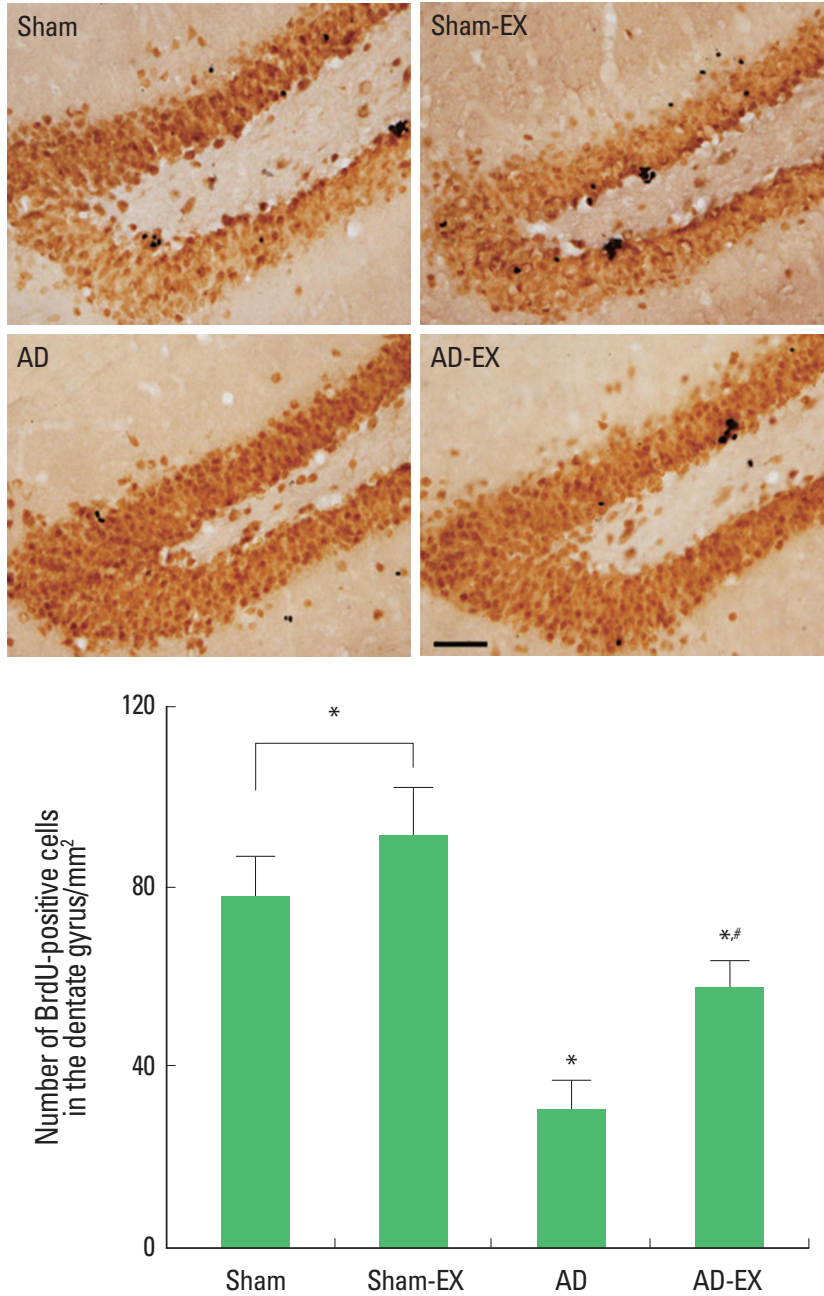

Fig. 2. Effect of treadmill exercise on cell proliferation in the hippocampal dentate gyrus. Upper: Phtomicrographs of 5-bromo-2'-deoxyuridine (BrdU) positive cells in the dentate gyrus. The scale bar represents $250 \mu \mathrm{m}$. Lower: Number of BrdU-positive cells in each group. Sham: Sham-operation group, Sham-EX: sham-operation and treadmill exercise group, AD: AD-induced group, AD-EX: AD-induced and treadmill exercise group. ${ }^{*}$ Represents $P<0.05$ compared to the sham-operation group. "Represents $P<0.05$ compared to the AD-induced group.

enhanced BDNF and TrkB expressions in the hippocampus of the AD-induced rats.

\section{DISCUSSION}

STZ at high dosage is commonly used to induce experimental diabetes mellitus in rats. However, ICV administration of STZ at low dosage in rodents does not alter peripheral glucose levels, and it is considered as the experimental model for late-onset sporadic AD (Muller et al., 2012; Sharma and Gupta, 2001). STZ-induced
$\mathrm{AD}$ is associated with the impairment of learning ability and memory performance (Agrawal et al., 2011; Muller et al., 2012).

In the present study, time for the successful performance with the number of error choice was higher and the number of the correct was lower in the AD-induced rats than those in the sham-operation rat. These results reveal that induction of $\mathrm{AD}$ incapacitated spatial learning ability.

Alterations of energy metabolism by deficits in brain insulin levels have been consistently linked with the dysfunctions of neurotropic factors and neuroplasticity in the experimental animal models and AD patients (Craft, 2006). In particular, during dysfunction of glucose consumption in the $\mathrm{AD}, \mathrm{BDNF}$ was down-regulated (Hubka, 2006). When the immune system is activated, the secretion of neurotrophic factors is inhibited, and these events might be the underlying mechanism of the AD-induced dysfunctions of memory and plasticity (Chadwick et al., 2011; Hubka, 2006). BDNF is an important intercellular signaling molecule mediating neurogenesis, synaptic plasticity, and cell survival, and it plays a crucial role in learning and memory processes (Lee and Son, 2009). Suppression of BDNF by AD decreased neurogenesis with reduced memory function (Kim et al., 2014). Impairment of neurogenesis in the hippocampus is closely implicated in the deterioration of learning ability and memory function (Heo et al., 2014; Kim et al., 2010). ICV administration of STZ decreased expressions of neurotrophic factors including BDNF and also reduced neurogenesis in the hippocampus (Arabpoor et al., 2012; Shonesy et al., 2012).

In the present study, induction of $\mathrm{AD}$ decreased the expressions of BDNF and TrkB in the hippocampus. Cell proliferation in the hippocampal dentate gyrus was also suppressed in the AD-induced rats. These results indicate that induction of $\mathrm{AD}$ reduced $\mathrm{BDNF}$ and $\operatorname{TrkB}$ expressions in the hippocampus, and resulted in the suppression of cell proliferation in the hippocampal dentate gyrus.

Physical exercise is known to alleviate memory deficits by aging and neurodegenerative diseases (Kim et al., 2013; Sim et al., 2005). Treadmill running and wheel running are well documented to increase new cell formation and survival in the rodent hippocampus (Kim et al., 2013; van Praag et al., 1999). BDNF is an important factor for exercise-induced cell proliferation in the hippocampus (Gómez-Pinilla et al., 1998; Kim et al., 2013). Clinical evidences have shown that exercise decrease the risk for developing cognitive impairment and dementia in AD (Archer, 2011).

In the present study, treadmill exercise enhanced BDNF and TrkB expressions in the hippocampus of rats with ICV injection of STZ, resulting in increment of cell proliferation in the hippocam- 


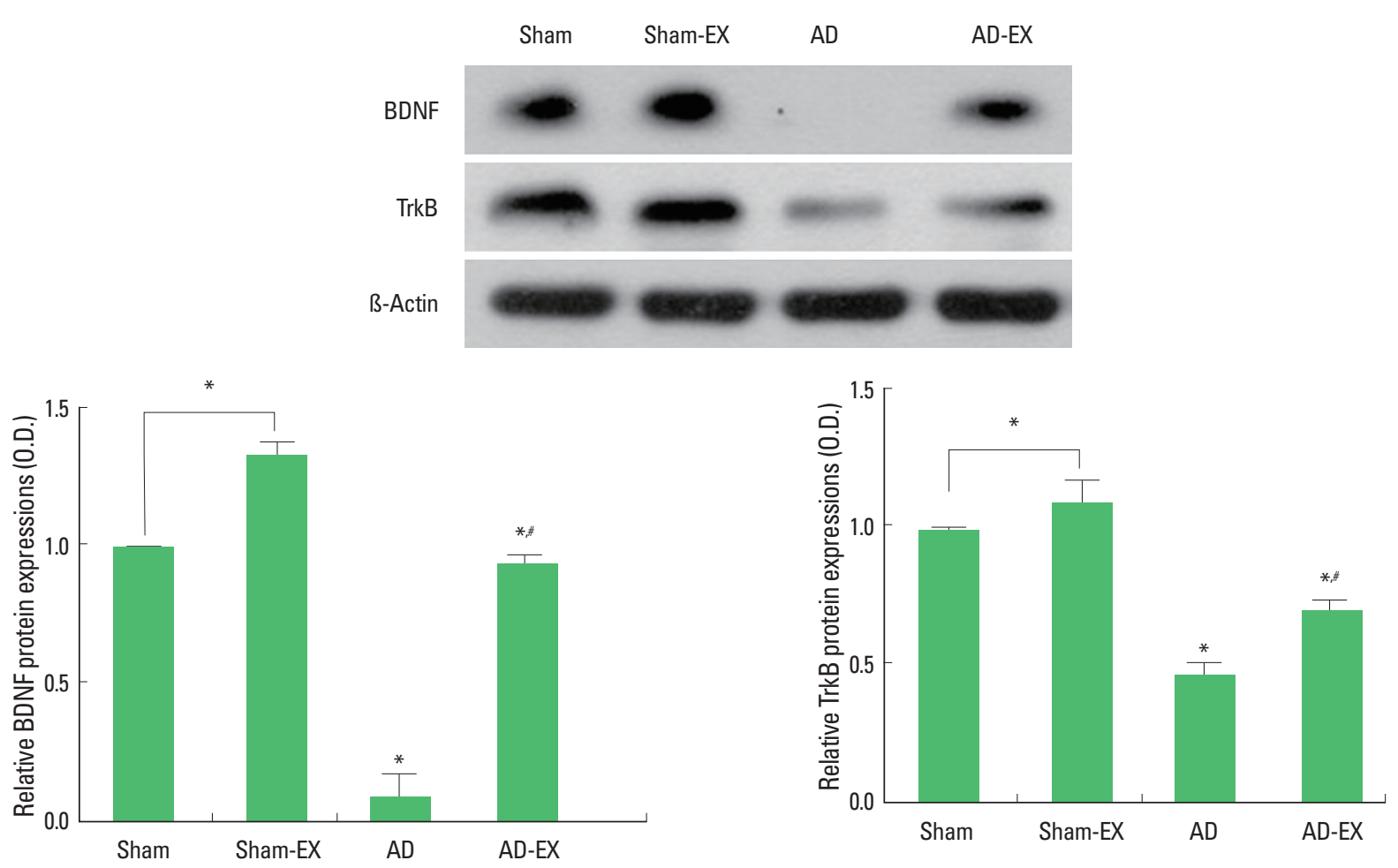

Fig. 3. Effect of treadmill exercise on BDNF and TrkB expressions in the hippocampus. Left: BDNF expression in the hippocampus. Right: TrkB expression in the hippocampus. Sham: Sham-operation group, Sham-EX: sham-operation and treadmill exercise group, AD: AD-induced group, AD-EX: AD-induced and treadmill exercise group. *Represents $P<0.05$ compared to the sham-operation group. "Represents $P<0.05$ compared to the AD-induced group.

pal dentate gyrus.

Here in this study, we have shown that treadmill exercise alleviated $\mathrm{AD}$-induced deficits of spatial learning ability through enhancing of cell proliferation in the hippocampus. The enhancing effect of treadmill exercise can be ascribed to the increasing effect of treadmill exercise on BDNF expression. The present study suggests that treadmill exercise can be a useful strategy for treating memory impairment induced by several neurodegenerative diseases.

\section{CONFLICT OF INTEREST}

No potential conflict of interest relevant to this article was reported.

\section{ACKNOWLEDGMENTS}

This paper was supported by research funds of Kunsan National University.

\section{REFERENCES}

Agrawal R, Tyagi E, Shukla R, Nath C. Insulin receptor signaling in rat hippocampus: A study in STZ (ICV) induced memory deficit model. Eur Neuropsychopharmacol 2011;21:261-273.

Alkam T, Nitta A, Mizoguchi H, Itoh A, Nabeshima T. A natural scaven $\urcorner g e r$ of peroxynitrites, rosmarinic acid, protects against impairment of memory induced by $\mathrm{A} \beta_{25-35}$. Behav Brain Res 2007;180:139-145.

Arabpoor Z, Hamidi G, Rashidi B, Shabrang M, Alaei H, Sharifi MR, Salami M, Dolatabadi HR, Reisi P. Erythropoietin improves neuronal proliferation in dentate gyrus of hippocampal formation in an animal model of Alzheimer's disease. Adv Biomed Res 2012;1:50-55.

Archer T. Physical exercise alleviates debilities of normal aging and Alzheimer's disease. Acta Neurol Scand 2011;123:221-238.

Braak H, Alafuzoff I, Arzberger T, Kretzschmar H, Del Tredici K. Staging of Alzheimer disease-associated neurofibrillary pathology using paraffin sections and immunocytochemistry. Acta Neuropathol 2006;112: 389-404.

Chadwick W, Mitchell N, Caroll J, Zhou Y, Park SS, Wang L, Becker KG, Zhang Y, Lehrmann E, Wood WH 3rd, Martin B, Maudsley S. Amitriptyline-mediated cognitive enhancement in aged 3×Tg Alzheimer's 
disease mice is associated with neurogenesis and neurotrophic activity. PLoS One 2011;6:e21660.

Craft S. Insulin resistance syndrome and Alzheimer disease: Pathophysiologic mechanisms and therapeutic implications. Alzheimer Dis Assoc Disord 2006;20:298-301.

de la Monte SM, Wands JR. Review of insulin and insulin-like growth factor expression, signaling, and malfunction in the central nervous system: Relevance to Alzheimer's disease. J Alzheimers Dis 2005;7:4561.

Dietrich MO, Spuch C, Antequera D, Rodal I, de Yébenes JG, Molina JA, Bermejo F, Carro E. Megalin mediates the transport of leptin across the blood-CSF barrier. Neurobiol Aging 2008;29:902-912.

Eichenbaum H. Hippocampus: cognitive processes and neural representations that underlie declarative memory. Neuron 2004;4:109-120.

Eriksson PS, Perfilieva E, Bjök-Eriksson T, Alborn AM, Nordborg C, Peterson DA, Gage FH. Neurogenesis in the adult human hippocampus. Nat Med 1998;11:1313-1317.

Freiherr J, Hallschmid M, Frey WH 2nd, Brünner YF, Chapman CD, Hölscher C, Craft S, De Felice FG, Benedict C. Intranasal insulin as a treatment for Alzheimer's disease: a review of basic research and clinical evidence. CNS Drugs 2013;27:505-514.

Gómez-Pinilla F, So V, Kesslak JP. Spatial learning and physical activity contribute to the induction of fibroblast growth factor: neural substrates for increased cognition associated with exercise. Neuroscience 1998;85:53-61.

Heo YM, Shin MS, Lee JM, Kim CJ, Baek SB, Kim KH, Baek SS. Treadmill exercise ameliorates short-term memory disturbance in scopolamine-induced amnesia rats. Int Neurourol J 2014;18:16-22.

Hosseini N, Alaei H, Reisi P, Radahmadi M. The effect of treadmill running on passive avoidance learning in animal model of Alzheimer disease. Int J Prev Med 2013;4:187-192.

Hoyer S. Causes and consequences of disturbances of cerebral glucose metabolism in sporadic Alzheimer disease: Therapeutic implications. Adv Exp Med Biol 2004;541:135-152.

Hubka P. Neural network plasticity, BDNF and behavioral interventions in Alzheimer's disease. Bratisl Lek Listy 2006;107:395-401.

Jee YS, Ko IG, Sung YH, Lee JW, Kim YS, Kim SE, Kim BK, Seo JH, Shin MS, Lee HH, Cho HJ, Kim CJ. Effects of treadmill exercise on memory and c-Fos expression in the hippocampus of the rats with intracerebroventricular injection of streptozotocin. Neurosci Lett 2008:443:188192.

Kim BK, Shin MS, Kim CJ, Baek SB, Ko YC, Kim YP. Treadmill exercise improves short-term memory by enhancing neurogenesis in amyloid beta-induced Alzheimer disease rats. J Exerc Rehabil 2014;10:2-8.

Kim SE, Ko IG, Kim BK, Shin MS, Cho S, Kim CJ, Kim SH, Baek SS, Lee
EK, Jee YS. Treadmill exercise prevents aging-induced failure of memory through an increase in neurogenesis and suppression of apoptosis in rat hippocampus. Exp Gerontol 2010;45:357-365.

Kim SE, Ko IG, Park CY, Shin MS, Kim CJ, Jee YS. Treadmill and wheel exercise alleviate lipopolysaccharide-induced short-term memory impairment by enhancing neuronal maturation in rats. Mol Med Rep 2013;7:31-36.

Kim SE, Ko IG, Shin MS, Kim CJ, Jin BK, Hong HP, Jee YS. Treadmill exercise and wheel exercise enhance expressions of neutrophic factors in the hippocampus of lipopolysaccharide-injected rats. Neurosci Lett 2013;538:54-59.

Lee E, Son H. Adult hippocampal neurogenesis and related neurotrophic factors. BMB Rep 2009 42:239-244.

Lee SW, Kim YS, Jun TW, Seo JH, Kim K, Shin MS, Kim CJ. The impact of duration of one bout treadmill exercise on cell proliferation and central fatigue in rats. J Exerc Rehabil 2013;9:463-469.

Lopez-Lopez C, Dietrich MO, Metzger F, Loetscher H, Torres-Aleman I. Disturbed cross talk between insulin-like growth factor I and AMP-activated protein kinase as a possible cause of vascular dysfunction in the amyloid precursor protein/presenilin 2 mouse model of Alzheimer's disease. J Neurosci 2007;27:824-831.

Muller AP, Zimmer ER, Kalinine E, Haas CB, Oses JP, Martimbianco de Assis A, Galina A, Souza DO, Portela LV. Physical exercise exacerbates memory deficits induced by intracerebroventricular STZ but improves insulin regulation of $\mathrm{H}_{2} \mathrm{O}_{2}$ production in mice synaptosomes. J Alzheimers Dis 2012;30:889-898.

Park JK, Lee SJ, Kim TW. Treadmill exercise enhances NMDA receptor expression in schizophrenia mice. J Ererc Rehabil 2014;10:15-21.

Salkovic-Petrisic M, Hoyer S. Central insulin resistance as a trigger for sporadic Alzheimer-like pathology: an experimental approach. J Neural Transm Suppl 2007;72:217-233.

Seo TB, Cho HS, Shin MS, Kim CJ, Ji ES, Baek SS. Treadmill exercise improves behavioral outcomes and spatial learning memory through up-regulation of reelin signaling pathway in autistic rats. J Ererc Rehabil 2013;9:220-229.

Sharma M, Gupta YK. Intracerebroventricular injection of streptozotocin in rats produces both oxidative stress in the brain and cognitive impairment. Life Sci 2001;68:1021-1029.

Shonesy BC, Thiruchelvam K, Parameshwaran K, Rahman EA, Karuppagounder SS, Huggins KW, Pinkert CA, Amin R, Dhanasekaran M, Suppiramaniam V. Central insulin resistance and synaptic dysfunction in intracerebroventricular-streptozotocin injected rodents. Neurobiol Aging 2012;33:5-18.

Sim YJ, Kim H, Kim JY, Yoon SJ, Kim SS, Chang HK, Lee TH, Lee HH, Shin MC, Shin MS, Kim CJ. Long-term treadmill exercise overcomes 
ischemia-induced apoptotic neuronal cell death in gerbils. Physiol Behav 2005;84:733-738.

van Praag H, Christie BR, Sejnowski TJ, Gage FH. Running, enhances neurogenesis learning, and long-term potentiation in mice. Proc Natl Acad Sci USA 1999;96:13427-13431. 